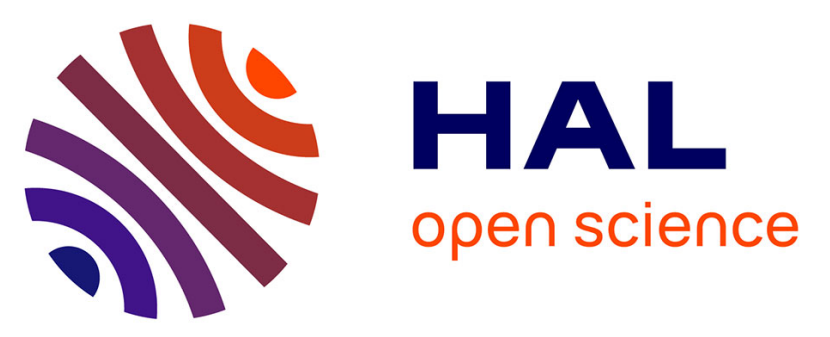

\title{
Plasmasphere observations with Cluster data supplemented with data from the Dynamics Explorer-1 and Van Allen Probes missions
}

Fabien Darrouzet, Johan de Keyser, Pierrette Décréau, Dennis Gallagher, Giuli Verbanac, Mario Bandic

\section{To cite this version:}

Fabien Darrouzet, Johan de Keyser, Pierrette Décréau, Dennis Gallagher, Giuli Verbanac, et al.. Plasmasphere observations with Cluster data supplemented with data from the Dynamics Explorer-1 and Van Allen Probes missions. 22nd EGU General Assembly, 2020, Online, France. 10.5194/egusphereegu2020-18386 . insu-03560747

\section{HAL Id: insu-03560747 https://hal-insu.archives-ouvertes.fr/insu-03560747}

Submitted on 8 Feb 2022

HAL is a multi-disciplinary open access archive for the deposit and dissemination of scientific research documents, whether they are published or not. The documents may come from teaching and research institutions in France or abroad, or from public or private research centers.
L'archive ouverte pluridisciplinaire HAL, est destinée au dépôt et à la diffusion de documents scientifiques de niveau recherche, publiés ou non, émanant des établissements d'enseignement et de recherche français ou étrangers, des laboratoires publics ou privés.

\section{(c)(1)}

Distributed under a Creative Commons Attribution| 4.0 International License 
EGU2020-18386

https://doi.org/10.5194/egusphere-egu2020-18386

EGU General Assembly 2020

(c) Author(s) 2022. This work is distributed under

the Creative Commons Attribution 4.0 License.

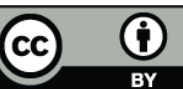

\title{
Plasmasphere observations with Cluster data supplemented with data from the Dynamics Explorer-1 and Van Allen Probes missions
}

\author{
Fabien Darrouzet ${ }^{1}$, Johan De Keyser ${ }^{1}$, Pierrette Décréau ${ }^{2}$, Dennis Gallagher ${ }^{3}$, Giuli Verbanac ${ }^{4}$, and \\ Mario Bandic ${ }^{5}$ \\ ${ }^{1}$ Royal Belgian Institute for Space Aeronomy (IASB-BIRA), Brussels, Belgium (Fabien.Darrouzet@aeronomie.be) \\ ${ }^{2}$ Laboratoire de Physique et Chimie de l'Environnement et de l'Espace (LPC2E), Orléans, France \\ ${ }^{3}$ Marshall Space Flight Center (MSFC), Huntsville, AL, USA \\ ${ }^{4}$ University of Zagreb, Zagreb, Croatia \\ ${ }^{5}$ Zagreb Astronomical Observatory, Zagreb, Croatia
}

Since 2000 the four Cluster spacecraft have crossed the Earth's plasmasphere along a polar orbit every 2.5 days, with various perigee altitudes (from 1.5 to $4 R_{E}$ ), different configurations (string of pearls, tetrahedron) and changing separations (from 10 to $100000 \mathrm{~km}$ ). The resulting dataset allows different types of inner magnetosphere studies and provides insight in plasmasphere dynamics, including changes in plasmapause position. Plasmaspheric plumes can also be studied on a case-by-case basis, in a statistical manner and in relation with wave activity (EMIC, electromagnetic rising tone, whistler waves).

Moreover, data from an old mission, Dynamics Explorer-1, have recently become available. In particular, densities and temperatures for many ions $\left(\mathrm{H}^{+}, \mathrm{He}^{+}, \mathrm{He}^{++}, \mathrm{O}^{+}\right.$, and $\left.\mathrm{O}^{++}\right)$have been derived from the RIMS (Retarding Ion Mass Spectrometer) instrument and are available from October 1981 to January 1985. Such composition data, not available from the Cluster satellites, allow in particular to analyze the distributions of those ions in the plasmasphere boundary layer, as a function of magnetic local time and geomagnetic activity.

Finally, since 2012, the two Van Allen Probes satellites are orbiting the inner magnetosphere in the magnetic equatorial plane and with a low perigee, allowing a crossing of the plasmasphere every 9 hours. The EMFISIS (Electric and Magnetic Field Instrument Suite and Integrated Science) instrument onboard both spacecraft can determine the electron density in a very large density range (up to $3000 \mathrm{~cm}^{-3}$ ) using several methods. This gives a different opportunity to analyze the plasmapause and plasmaspheric plumes from a different perspective. 